\title{
An Experimental Study on performance and emission characteristics of multi cylinder CRDI diesel engine fueled with Ethanol, Acid oil based Biodiesel and Diesel blends
}

\author{
S. Rajesh ${ }^{\# *}$, B. M. Kulkarni` and S. Kumarappa ${ }^{\#}$ \\ \#Department of Mechanical Engineering, ^Department of Chemical Engineering, VTU, Bapuji Institute of Engineering \& Technology, Davangere \\ -577 004, Karnataka India
}

Accepted 27 Feb 2017, Available online 28 Feb 2017, Vol.7, No.1 (Feb 2017)

\begin{abstract}
This experimental investigation discusses the use of biodiesel as an additive for diesel and ethanol (diesohol) mixtures for diesel engine applications. The biodiesel was produced from Acid oil, a by-product of vegetable oil processing plant to obtain its ester called as acid oil methyl ester (AOME) and was consequently blended with diesel and ethanol respectively using $50 \%$ by volume of biodiesel and by varying $4 \%, 8 \%, 12 \%$ and $16 \%$ by volume of ethanol with $46 \%$, $42 \%, 38 \%$ and $34 \%$ by volume of diesel respectively. The physical and chemical properties of these fuels and their blends were obtained to determine their applicability for the common rail direct injection (CRDI) engine. The foremost objective of current effort is the testing of compression ignition engine with increased proportion of biodiesel in diesel-ethanol blends and comparing the performance with diesel engine operation. The results showed that the fuel properties of the blends satisfy the requirement of regular diesel engine, although tendency of more carbon residue is observed with increased fraction of biodiesel. The blends were then tested in a four cylinder CRDI engine for different loads at different engine speeds of 1200, 1500 and1800rpm respectively. Performance, emission characteristics of the engine fuelled with the selected blends were then compared with standard diesel fuel operation. The Investigations revealed, the decrease in brake thermal efficiency, increase in brake specific fuel consumption, increased carbon monoxide and hydrocarbon emissions with increase in alcohol concentration in the blends, whereas NOx emissions were reduced. Further with increase in speed from 1200 to 1800 rpm, brake thermal efficiency increases but carbon monoxide and hydrocarbon emissions decreased while NOx emissions were increased significantly. Beyond 1800 rpm tendency of Knocking was observed for engine operation.
\end{abstract}

Keywords: Common Rail Direct Injection (CRDI) engine, Ethanol, Acid oil methyl ester (AOME), Engine performance, Emissions.

\author{
Abbreviations \\ AOME- Acid Oil Methyl Ester \\ BTE-Brake Thermal Efficiency \\ BSFC-Brake Specific Fuel Consumption \\ CC-Combustion Chamber \\ CRDI-Common Rail Direct Injection \\ CR-Compression Ratio \\ CO-Carbon Monoxide \\ FFA-Free Fatty Acid \\ HC-Hydrocarbon \\ IP-Injection Pressure \\ $\mathrm{NO}_{\mathrm{x}}$-Oxides of Nitrogen \\ PM-Particulate Matter \\ E:B:D-Ethanol-biodiesel-diesel
}

\section{Introduction}

*Corresponding author: S. Rajesh

DOI: http://Dx.Doi.Org/10.14741/Ijcet/22774106/7.1.2017.40
Over the past decades, there has been an increase in effort to reduce the reliance on petroleum fuels for energy generation and transportation in India and throughout the world. Today, diesel engines are widely used in transportation industry and agricultural areas because of their high fuel efficiency and ease of operation (Kraipat Cheenkachorn et al, 2006, A Demirbas et al, 2008). The demand for diesel engines has been continuing to increase worldwide as a result of expanding industrialization (Y. Ma et al. 2013). This is because diesel engines have certain advantages compared to spark ignition engines such as low fuel consumption, high engine torque and longevity (S. H. Park et al, 2013). Despite these advantages, today diesel engines are among the leading factors that cause air pollution (M. E. A. Fahd, et al, 2013, A.J.Torregrosa et $a l, 2013)$. Due to the impact of environmental pollution there is an imperative need for suitable alternate fuels for use in diesel engine without any 
modification (Vivek Pathak, et al, 2013). Among the proposed alternative fuels, biodiesel and diesohol (a blend of ethanol with regular diesel) have received much attention in recent years for diesel engines due to their advantages as the renewable and domestically produced energy resources. Moreover, the studies have shown that they are environmental friendly because there is substantial reduction of unburned hydrocarbons (HC), Carbon Monoxide (CO) and Particulate Matter (PM) emission when it is used in conventional diesel engine. However, ethanol and diesel fuels are inherently immiscible because of their difference in chemical structures and characteristics, and therefore need an effective emulsification technique for being an emulsion (C.A. Sharp, et al, 1996). The emulsifier would reduce the interfacial tension force and increase the affinity between the two liquid phases, leading to emulsion stability (C.Y. Lin et al, 2003).

A suitable emulsifier for ethanol and diesel fuel is suggested to contain both lipophilic part and hydrophilic part, in order to obtain an emulsion of diesohol. Such chemical structures can be found in biodiesel. Hence biodiesel can be used as an emulsifier for diesohol (G. J. Suppes, et al, 2001, G. Anastopoulos, et al, 2001). The biggest advantage in the use of biodiesel fuel is that it can be used without performing any modifications on the engine (D. H. Qi, et al, 2010, H. Aydogan, et al, 2011). A review of the studies in the literature show that a good number of researchers focused on the use of ethanol in diesel engines. Shi et al. (X. Shi , et al, 2006) investigated the effects of ethanol-biodiesel-diesel fuel blends on engine emissions. In their study, they stated that the amount of PM in exhaust emissions decreased, whereas an increase was observed in the amount of carbon dioxide $\left(\mathrm{CO}_{2}\right)$. (P. V. Bhale, et al, 2009) investigated the effects of mahua biodiesel and ethanol blends on engine performance and emissions. It was stated that $\mathrm{CO}$ and NOx emissions decreased, whereas HC emissions increased as the result of the experiments conducted by using diesel fuel containing $20 \%$ ethanol $(\mathrm{X}$. Lu, et $a l, 2005)$. The use of bioethanol in diesel engines provides a decrease in the amount of particulate matter (PM) in exhaust emissions.

The decrease in PM (smoke) is related to the amount of oxygen contained in fuel blends (D. B. Hulwan et al, 2011, H. Rahimi et al, 2009, N. Yilmaz et $a l, 2012$, X. Shi et al, 2005). It may be noted that biodiesel has higher viscosity and hence requires higher injection pressure however, the presence of ethanol decreases viscosity of the ternary mixture and also raises the oxygen content in the fuel blend ( $\mathrm{T}$. Krishnaswamy et al, 2012). Several investigations were carried out to check feasibility studies on the utilization of biodiesels for use in CRDI engines. In CRDI engines fuel can be injected with high injection pressures (IP) of up to 2500 bar which enables to atomize fuel into very finer droplets (B P Pundir et al, 2007). Ethanol is an attractive oxygenate and can be blended with diesel by using biodiesel as an emulsifier. Solubility test and engine studies on ethanol, biodiesel and diesel blends reported that $5 \%$ ethanol, $15 \%$ biodiesel and $80 \%$ diesel blend was most suitable due to their acceptable properties and lower emissions (K Prommes et al, 2007). Diesel-ethanol-biodiesel fuelled multi cylinder Diesel engines showed increased BSFC for higher ethanol content while the brake thermal efficiency improved for higher ethanol content in the blends. Results showed that smoke is reduced remarkably at higher loads but NOx emission showed variation in the trends depending on engine operating conditions while $\mathrm{CO}$ emissions drastically increased at lower loads (D. B. Hulwan et al, 2010). C. Sayin et al, (2010) studied the effect of ethanol-diesel [E5 and E10] fuel blends in a single cylinder DI diesel engine and found that BTE, $\mathrm{CO}, \mathrm{HC}$ and smoke emissions decreased while BSFC and NOx emission increased with Ethanol-diesel blends. Investigations on effect of bioethanol with rapeseed methyl ester and diesel blends in a 4 cylinder light duty diesel engine showed drastic smoke and NOx emissions reduction while higher BSFC, $\mathrm{CO}$ and $\mathrm{HC}$ emission were observed with bioethanol blends (H.G. How et al, 2014). L. Zhu et al, (2011) studied the effect of ethanol blends in a 4 cylinder DI diesel engines and the results indicated that ethanol biodiesel blends showed higher BTE and lower NOx and PM emissions compared to diesel fuel operation. Increasing the ethanol amount in the blends resulted in higher BSFC, $\mathrm{HC}$ and $\mathrm{CO}$ emissions. The review of previous studies on use of blends of ethanolbiodiesel-diesel disclose that performance of engine is almost analogous to that with diesel with reduced PM emissions whereas diversified outcomes were reported for $\mathrm{CO}, \mathrm{HC}$ and NOx emissions. Additional studies also revealed an increase or decrease or no substantial variation in $\mathrm{CO}$ emissions. Correspondingly contrary results were stated about NOx emissions.

When previous studies are examined, it can be seen that most of the researchers used ethanol and biodiesel at a low ratio in diesel-ethanol and biodiesel blends. The aim of the present study is to increase the percentage of the biodiesel used in diesel engines by adding low proportions of ethanol in diesel-ethanolbiodiesel blends keeping the important fuel properties within acceptable limits. Fuel blends were prepared in order to have high oxygen content and to study its effect on the engine performance and emissions. The fuel blends were tested in a diesel engine with a multi cylinder common rail fuel injection system for varied ethanol and diesel proportions.

The engine performance was compared with that fueled with pure diesel. Further the study also emphasize on the consequence of speed and load on performance and emission characteristics of CRDI engine fuelled with diesel-ethanol and an ester of nonedible oil to optimize the speed for best BTE. Critical conclusions were finally made from this experimental study. 
Table 1 Fuel properties of Acid oil

\begin{tabular}{|c|c|c|c|}
\hline Sl. No. & Method & Property & Value \\
\hline 1 & ASTM D-4052 & Specific gravity & 0.914 \\
\hline 2 & ASTM D-445 & Kinematic viscosity $(\mathrm{cSt})$ & 48.4 \\
\hline 4 & ASTM D-2015 & Heating value $(\mathrm{M} / \mathrm{kg})$ & 36.6 \\
\hline 5 & ASTM D-9390 & Flash point $\left({ }^{\circ} \mathrm{C}\right)$ & 212 \\
\hline 6 & ASTM D-2500 & Pour point $\left({ }^{\circ} \mathrm{C}\right)$ & 11 \\
\hline 7 & ASTM D-613 & Cetane number & 39.5 \\
\hline 8 & ASTM D-664 & Acid value $(\mathrm{mgKOH} / \mathrm{gr})$ & 198 \\
\hline 9 & ASTM D-5768 & Iodine value & 122 \\
\hline
\end{tabular}

Table 2 Properties of base fuels

\begin{tabular}{|c|c|c|c|c|}
\hline Property & Method & Ethanol & Acid oil methyl ester Biodiesel & Diesel \\
\hline Density $\left(\mathrm{kg} / \mathrm{m}^{3}\right)$ & ASTM D-4052 & 789 & 885 & 819 \\
\hline Kinematic viscosity (cst) & ASTM D-445 & 1.21 & 5.8 & 2.94 \\
\hline Flash point $\left({ }^{\circ} \mathrm{C}\right)$ & ASTM D-9390 & 14 & 97 & 57 \\
\hline Fire point $\left({ }^{\circ} \mathrm{C}\right)$ & ASTM D-9390 & 18 & 113 & 64 \\
\hline Calorific value $(\mathrm{kJ} / \mathrm{kg})$ & ASTM D-2015 & 26843 & 41577 & 44189 \\
\hline Cloud point $\left({ }^{\circ} \mathrm{C}\right)$ & ASTM D-4052 & -7 & 8 & 2 \\
\hline Pour point $\left({ }^{\circ} \mathrm{C}\right)$ & ASTM D-2500 & $\leq-35$ & 2 & -16 \\
\hline Cetane number & ASTM D-613 & 8 & 57 & 52 \\
\hline Carbon residue $\%$ & ASTM D-524 & - & 1.96 & 0.5 \\
\hline Acid value $(\mathrm{mgKOH} / \mathrm{gr})$ & ASTM D-664 & - & 0.68 & - \\
\hline
\end{tabular}

Table 3 Properties of blends

\begin{tabular}{|c|c|c|c|c|c|}
\hline Blends $\longrightarrow$ & \multirow{2}{*}{ Method } & \multirow{2}{*}{$\begin{array}{c}\mathrm{E}: \mathrm{B}: \mathrm{D} \\
04: 50: 46\end{array}$} & \multirow{2}{*}{$\begin{array}{c}\mathrm{E}: \mathrm{B}: \mathrm{D} \\
08: 50: 42\end{array}$} & \multirow{2}{*}{$\begin{array}{c}\mathrm{E}: \mathrm{B}: \mathrm{D} \\
12: 50: 38\end{array}$} & \multirow{2}{*}{$\begin{array}{c}\text { E : B : D } \\
16: 50: 34\end{array}$} \\
\hline Properties $\downarrow$ & & & & & \\
\hline Density $\left(\mathrm{kg} / \mathrm{m}^{3}\right)$ & ASTM D-4052 & 836.2 & 834.1 & 831.4 & 829 \\
\hline Kinematic viscosity (cSt) & ASTM D-445 & 4.9 & 4.38 & 3.78 & 3.42 \\
\hline Flash point $\left({ }^{\circ} \mathrm{C}\right)$ & ASTM D-9390 & 45 & 38 & 30 & 24 \\
\hline Fire point $\left({ }^{\circ} \mathrm{C}\right)$ & ASTM D-9390 & 52 & 44 & 36 & 29 \\
\hline Calorificvalue (kJ/kg) & ASTM D-2015 & 42169 & 40252 & 39170 & 37680 \\
\hline Cloud point $\left({ }^{\circ} \mathrm{C}\right)$ & ASTM D-4052 & 3 & 2 & 1 & -1 \\
\hline Pour point $\left({ }^{\circ} \mathrm{C}\right)$ & ASTM D-2500 & -1 & -4 & -6 & -7 \\
\hline Cetane number & ASTM D-613 & 52.38 & 50.62 & 48.71 & 45.83 \\
\hline Carbon residue \% & ASTM D-524 & 0.32 & 0.29 & 0.21 & 0.18 \\
\hline $\begin{array}{c}\text { Copperstrip corrosion } \\
\text { test }\end{array}$ & ASTM D-130 & $1 b$ & $1 b$ & $1 b$ & $1 b$ \\
\hline
\end{tabular}

\section{Materials and Methods}

In India, non-edible oils are suggested for the production of biodiesel as the country imports edible oil to meet its requirements and the prices of edible oils are higher than that of petroleum diesel. Usage on non-edible oils is not only economical but also gives value addition to waste oils. Hence in this work acid oil a non-edible by product of vegetable oil refineries is used for biodiesel production. Acid oil predominantly consist of long chain free fatty acid mixture and possess fuel properties which are different than those of diesel fuel. Heating values are slightly lower while viscosity and ignition values are higher for this oil compared to diesel. Viscosity of acid oil is reduced by a modified esterification process using acid type of catalysts. Since acid oil consists of Free Fatty Acid (FFA) and moisture far excess than allowable limits conventional transesterification process does not provide any desired result. In this direction a new method of esterification process that was developed at the institute was employed to produce biodiesel from acid oil. Acid oil used for the study was obtained from Chitradurga sunflower oil mill, a nearby medium scale oil processing unit which produces around 600 metric tons of acid oil annually. In the method adopted esterification was done using extractive distillation principle. The esterification was carried out in a closed type of reactor provided with changeable electrical heating unit, a incessant methanol recirculation and methanol vapour evading arrangements. Reaction mixture was maintained at $70^{\circ} \mathrm{C}$, methanol-water vapours were condensed, reprocessed back throughout the course of reaction. Excess methanol used was recovered and reused in succeeding batches. Resultant crude ester mixture was washed thrice with equal 
amounts of water and was allowed to stand overnight. Water settled at the bottom was separated. Top ester layer produced was separated and batch distilled. Escaping vapours were condensed and collected as neat biodiesel. Reactor used was of capacity to process ten litres of acid oil per batch. The yield of 70-75\% was obtained as neat biodiesel (B. M. Kulkarni et al, 2008). Diesel fuel used for the study was purchased from a nearby Indian oil outlet and was tested for its fuel properties to ensure its compliance to standard specifications. The absolute ethanol of $99.5 \%$ pure was used for the study and was procured from $\mathrm{M} / \mathrm{s}$ Samson's distilleries Duggavati, Davanagere District, Karnataka, India. Ethanol of $99.5 \%$ pure is only used because the inter-solubility of three fuels used was not limited and they could be mixed into a homogenous solution at any ratio used. The diesel, biodiesel (AOME) and ethanol were mixed into a homogenous mixture by a magnetic stirrer and blends with(\%v/v) 4, 8, 12, 16\% of ethanol, $50 \%$ of biodiesel and $46,42,38$ and $34 \%$ of diesel were prepared. The properties of acid oil and base fuels and their blends were found out as per ASTM standards and are shown as below. Table 1 shows the fuel properties of Acid oil. Table 2 shows the properties of base fuels like ethanol, AOME and diesel respectively. Table 3 shows the properties of AOME and its blends with diesel and alcohol used in the study.

\subsection{Experimental methodology}

Engine tests were carried out for different speeds of 1200, 1500 and1800 rpm correspondingly and the engine was operated from no load to full load conditions. Ethanol-Biodiesel-Diesel (E:B:D) blends were prepared in the ratios of 04:50:46, 08:50:42, 12:50:38 and 16:50:34 respectively. Series of engine tests were conducted using these fuel blends. For each test six readings of fuel consumption for calculation of Brake thermal efficiency, Brake specific fuel consumption and six readings of exhaust emissions viz., CO, HC, NOx, were recorded and are averaged out These results were used for the analysis purpose and were finally compared with standard diesel fuel operation.

\subsection{Experimental Setup of CRDI Diesel Engine}

Figure 1 shows the schematic diagram of multi cylinder CRDI experimental test rig used in the study. Exhaustive experiments were conducted on a four cylinder, 4-stroke CRDI engine and the specifications of the engine are shown in table 4. Experiments were carried out for three engine speeds viz., 1200, 1500 and $1800 \mathrm{rpm}$ and the engine was run from no load to full load conditions.

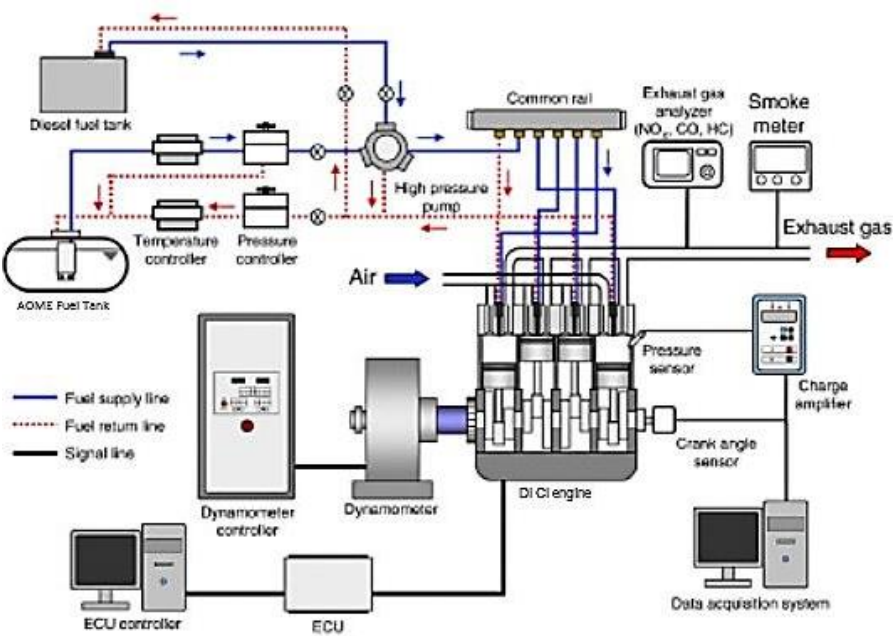

Fig. 1 Schematic diagram of multi cylinder CRDI experimental test rig

Table 4 Specifications of CI engine

\begin{tabular}{|c|c|c|}
\hline Sl. No. & Parameter & Specifications \\
\hline 1 & Make & Maruti Suzuki \\
\hline 2 & Engine Type & 1.3 ltr CRDI engine \\
\hline 3 & Static injection timing & 24 obTDC \\
\hline 4 & No of cylinders & Four cylinder \\
\hline 5 & No of strokes & Four stroke \\
\hline 6 & Fuel & H. S. Diesel \\
\hline 7 & Rated power & 74bhp@4000rpm \\
\hline 8 & Maximum torque and Engine speed & $190 \mathrm{Nm} @ 2000 \mathrm{rpm}$ \\
\hline 9 & Cylinder diameter (Bore) & $0.0696 \mathrm{~m}$ \\
\hline 10 & Stroke length & $0.082 \mathrm{~m}$ \\
\hline 11 & Compression ratio & $17.5: 1$ \\
\hline
\end{tabular}




\section{Results and Discussions}

\subsection{Effect of fuel blends on brake thermal efficiency}
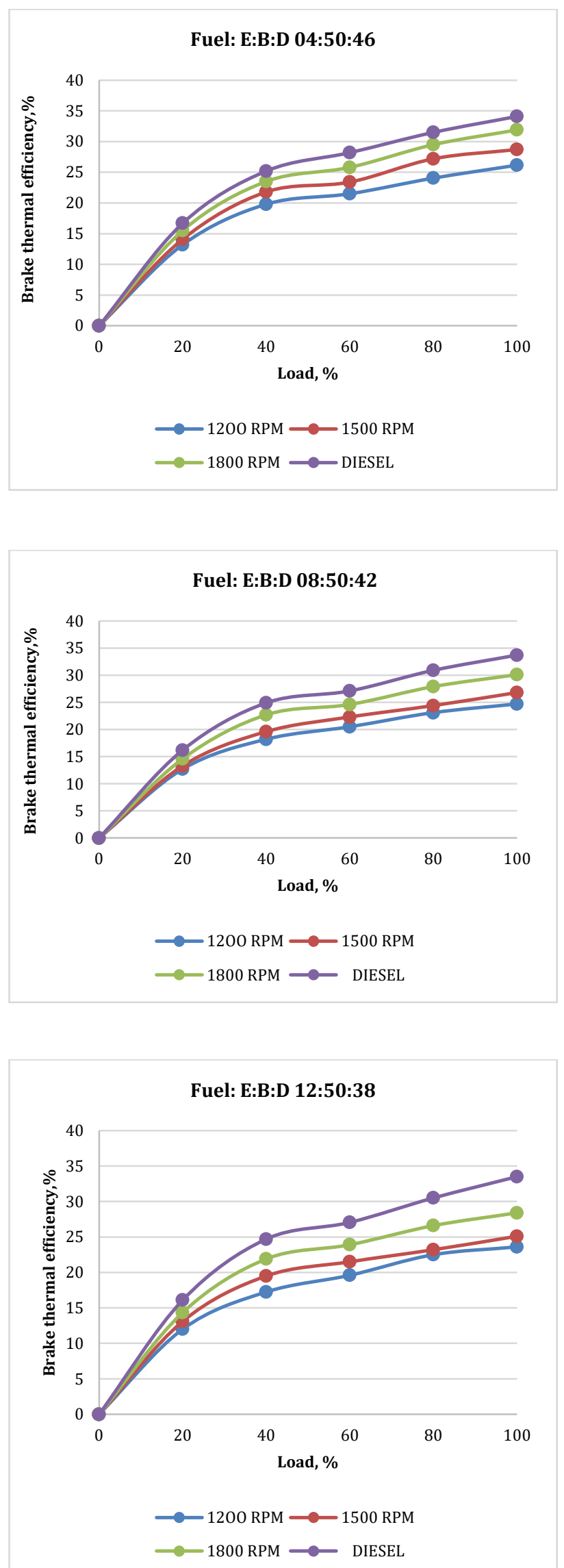

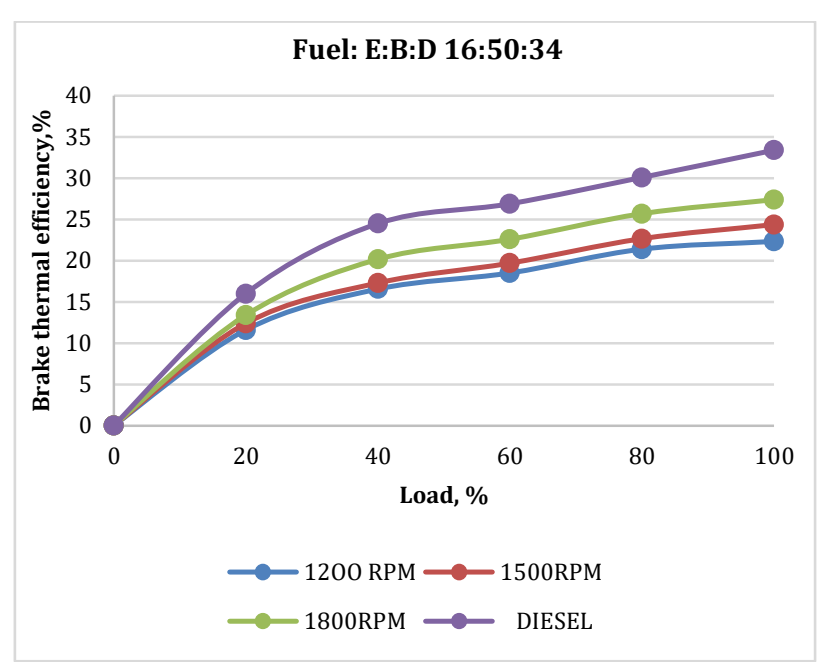

Figure 2 Effect of speed on Brake Thermal Efficiency of fuel blends at different loads

Figure 2 shows the effect of engine speed on brake thermal efficiency of CRDI engine for selected fuel blends operation at different loads. From the figure it follows that the BTE increases with load for all the engine speeds for all fuel blends considered, but showed deprived performance compared to diesel. The decrease in BTE for fuel blends when compared to diesel is mainly attributed to their lower energy content, higher viscosity and higher fuel consumption for the same engine power output. Further the BTE increases with increase in speed from 1200 to 1800 for all the fuel blends. However as the ethanol concentration in the fuel blends increases BTE slightly decreased. Higher latent heat of vaporization of the ethanol leads to increased heat losses while the lower cetane number leads to longer ignition delay and hence incomplete combustion occurs as more fuel is burned in the expansion stroke; and reduction in heating value of the fuel blends further leads to increase in the volume of the fuel injected to develop the same engine power. Therefore combined effect of all these factors will lead to decrease in BTE.

3.2 Effect of fuel blends on Brake specific fuel consumption

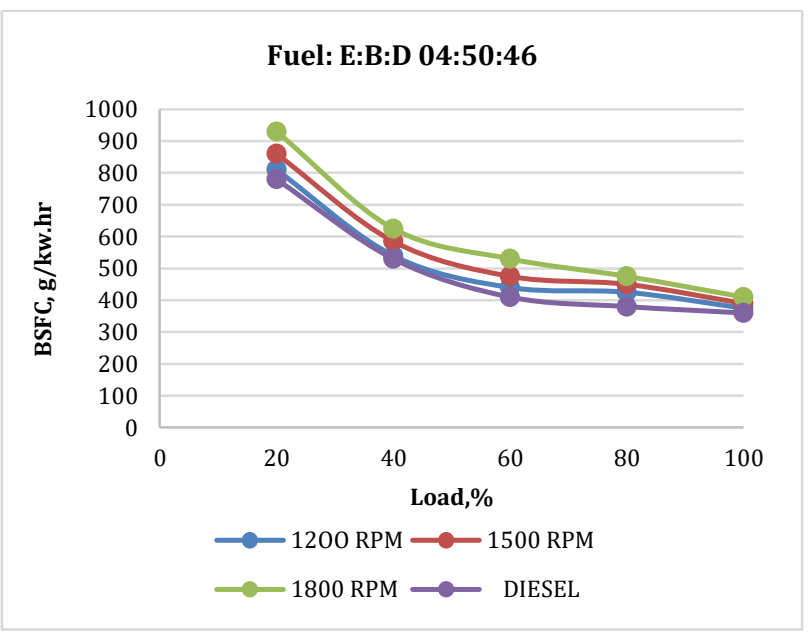



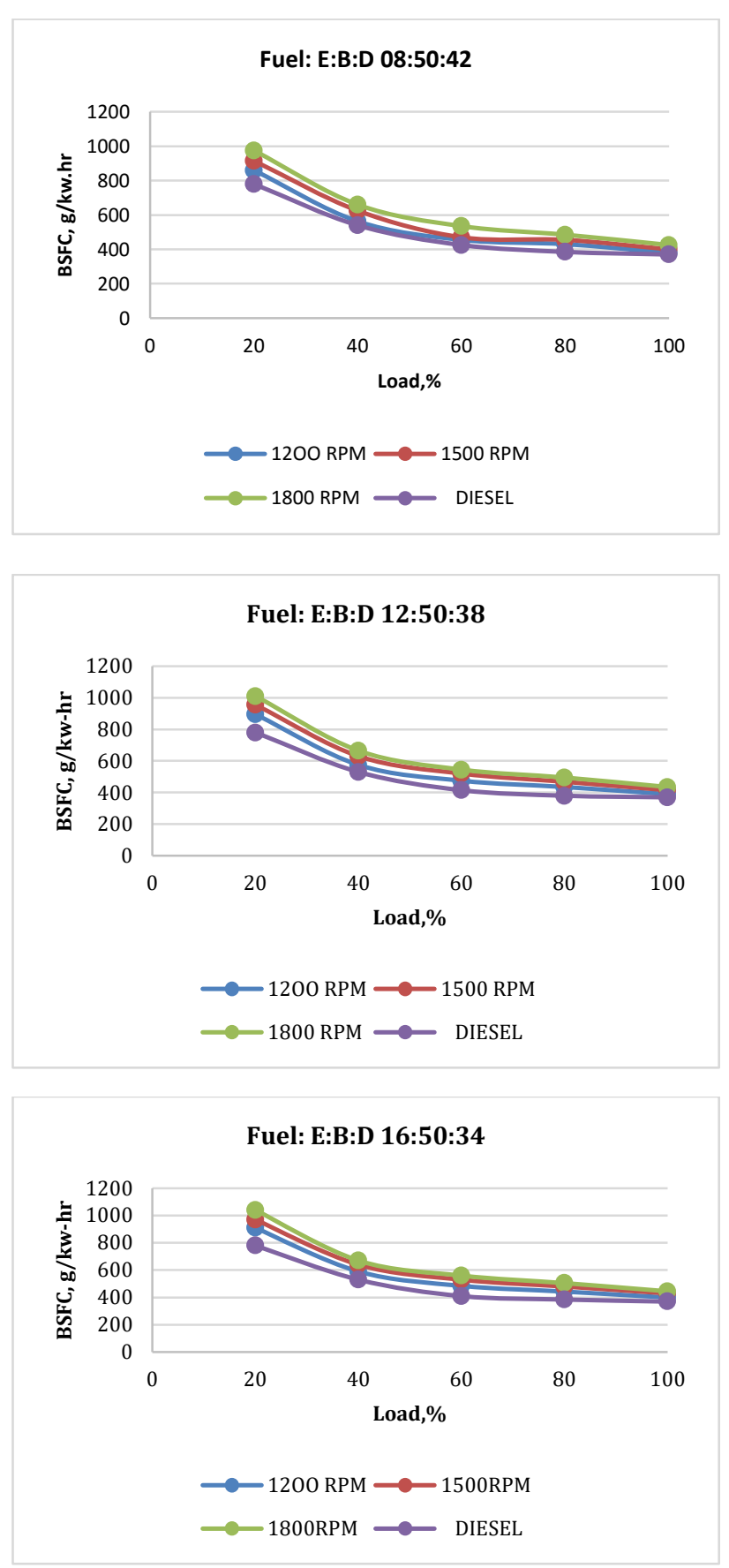

Figure 3 Effect of speed on Brake specific fuel consumption of fuel blends at different loads

A normal trend of decrease in BSFC with load is observed for diesel fuel as well as the blends, at all speeds as shown in figure 3. This could be explained by the fact that; as the engine load increases, the rate of increasing brake power is much more than that of the fuel consumption. BSFC is also increased for the blends at all loads and speeds compared to diesel fuel. It is also observed that the BSFC is increased with increase in ethanol proportion in the blends. This is mainly due to decrease in calorific value of the blends; requiring additional fuel to produce the same power. Increased frictional and incomplete combustion losses at higher speeds would have increased the specific fuel consumption.

\section{Emissions}

\subsection{HC Emissions}
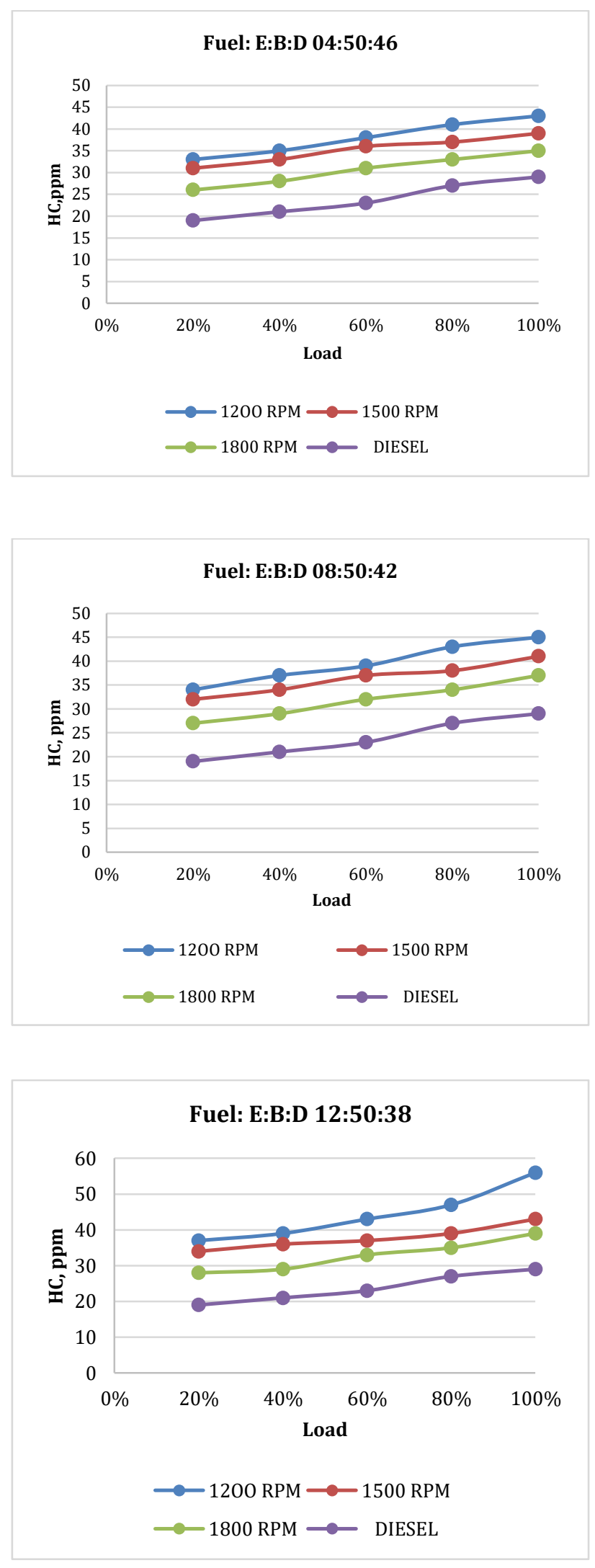


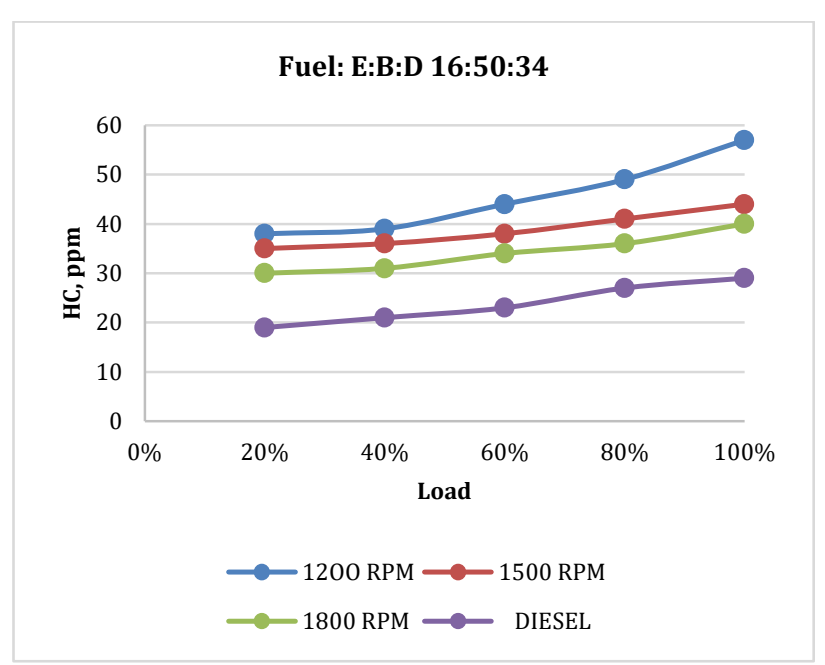

Figure 4 Effect of speed on HC emission of fuel blends at different loads

Figure 4 shows the effect of engine speed on HC emissions of CRDI engine for selected fuel blends operation at different loads. The HC emission increases with increase in loads for all blends at all speeds and is higher when compared to diesel. Increase of $\mathrm{HC}$ with the addition of ethanol in the fuel blends is mainly due to the higher heat of evaporation of the ethanol blends which cause slower evaporation and poorer air-fuel mixing that may result in increased spray penetration causing unwanted fuel impingement on the chamber walls which may contribute to increased HC emission. Further lower cetane and viscous effects due to higher biodiesel content with ethanol negate the positive effect of oxygen content in the blends. Higher engine speed lowered HC emission for all fuel blends. This phenomenon can be attributed to better mixing of air and fuel mixtures observed at higher speeds.

\subsection{CO Emissions}

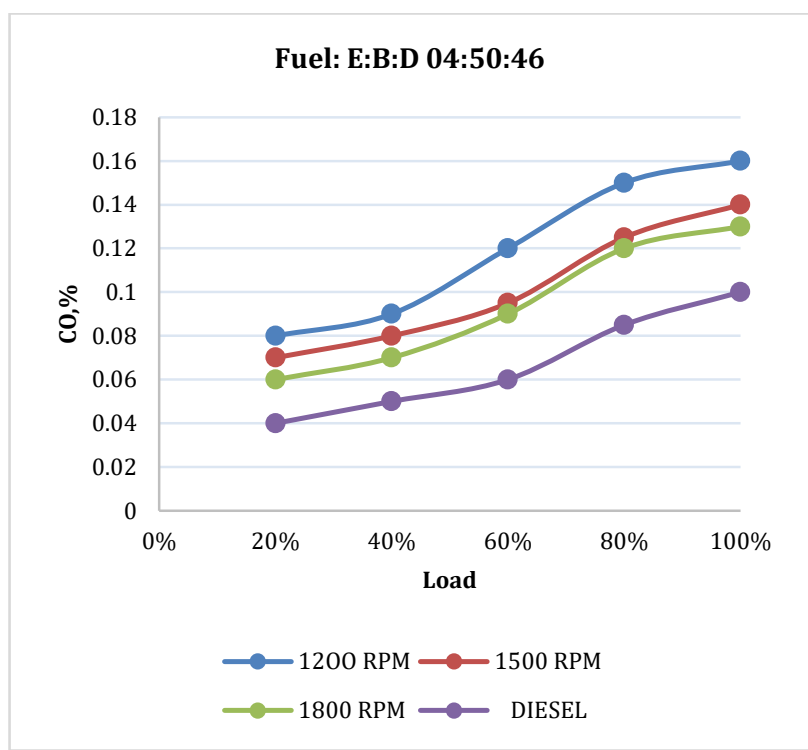

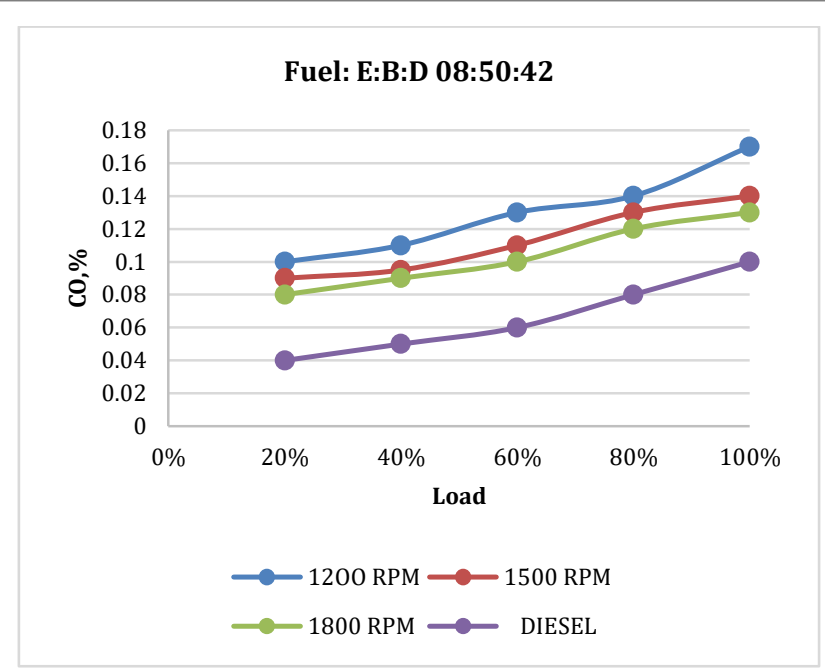
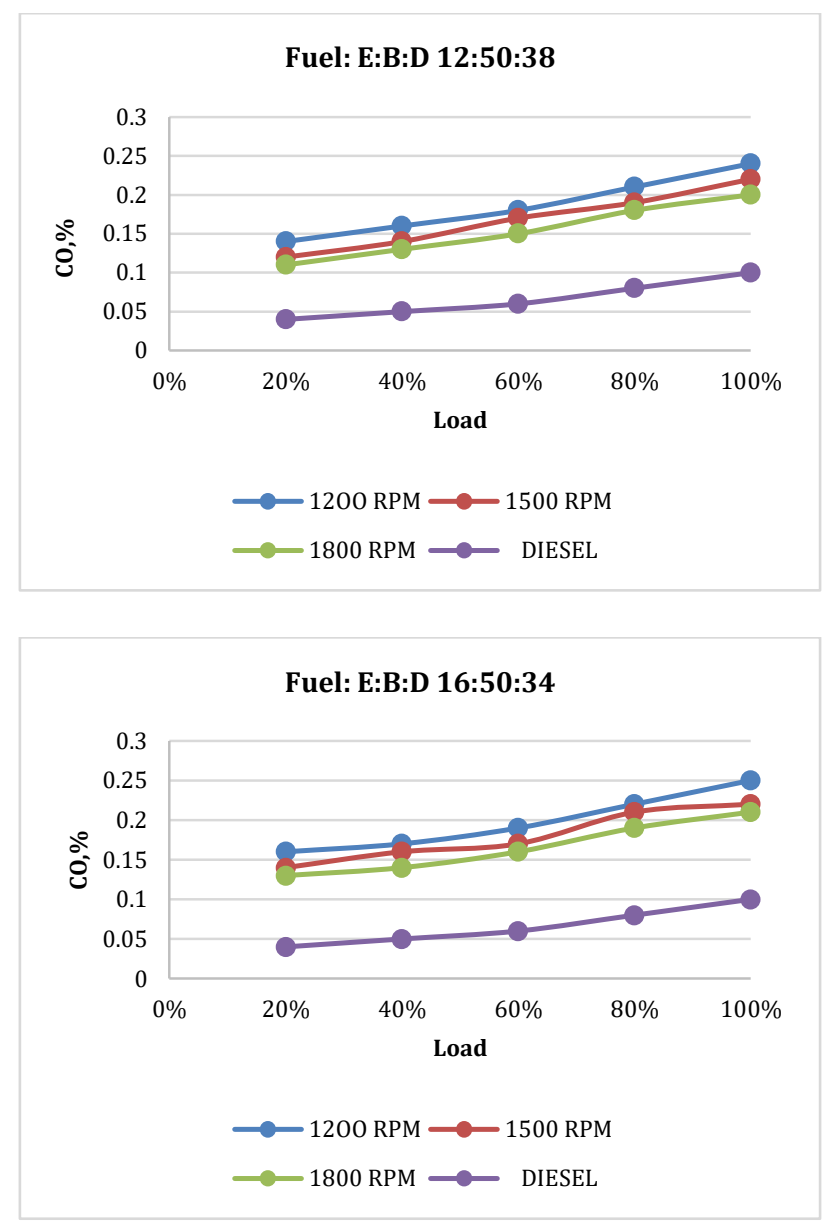

Figure 5 Effect of speed on CO emission of fuel blends at different loads

Figure 5 shows the effect of engine speed on CO emission of CRDI engine for selected fuel blends operation at different loads. Carbon monoxide emissions increased with increased loads at all speeds for all blends when compared to diesel operation. Increased $\mathrm{CO}$ emissions with blends is mainly due to higher biodiesel concentration which further leads to improper combustion associated with shorter combustion periods. Further lower cetane number of blends increase ignition delay that causes higher 
amount of fuel accumulation before the combustion process starts.

Higher viscosity of blends degrade spray characteristics and cause improper mixture formation. Higher amount of improper mixtures and shorter combustion period results in poor combustion of blends which plays an important role for CO emissions. Higher the engine speed, lower will be the CO emissions for all the fuel blends tested. Improved mixing of air and fuels occurs at higher speeds which provide enhanced turbulence. As ethanol content increases in blends CO emissions increases. This is because higher latent heat of vaporization of ethanol leads to increased heat losses and the lower cetane number leads to longer ignition delay and hence incomplete combustion occurs as more fuel burns in the expansion stroke. Further reduction in heating value of the fuel blends increase the volume of fuel injected which leads to improper mixture formation.
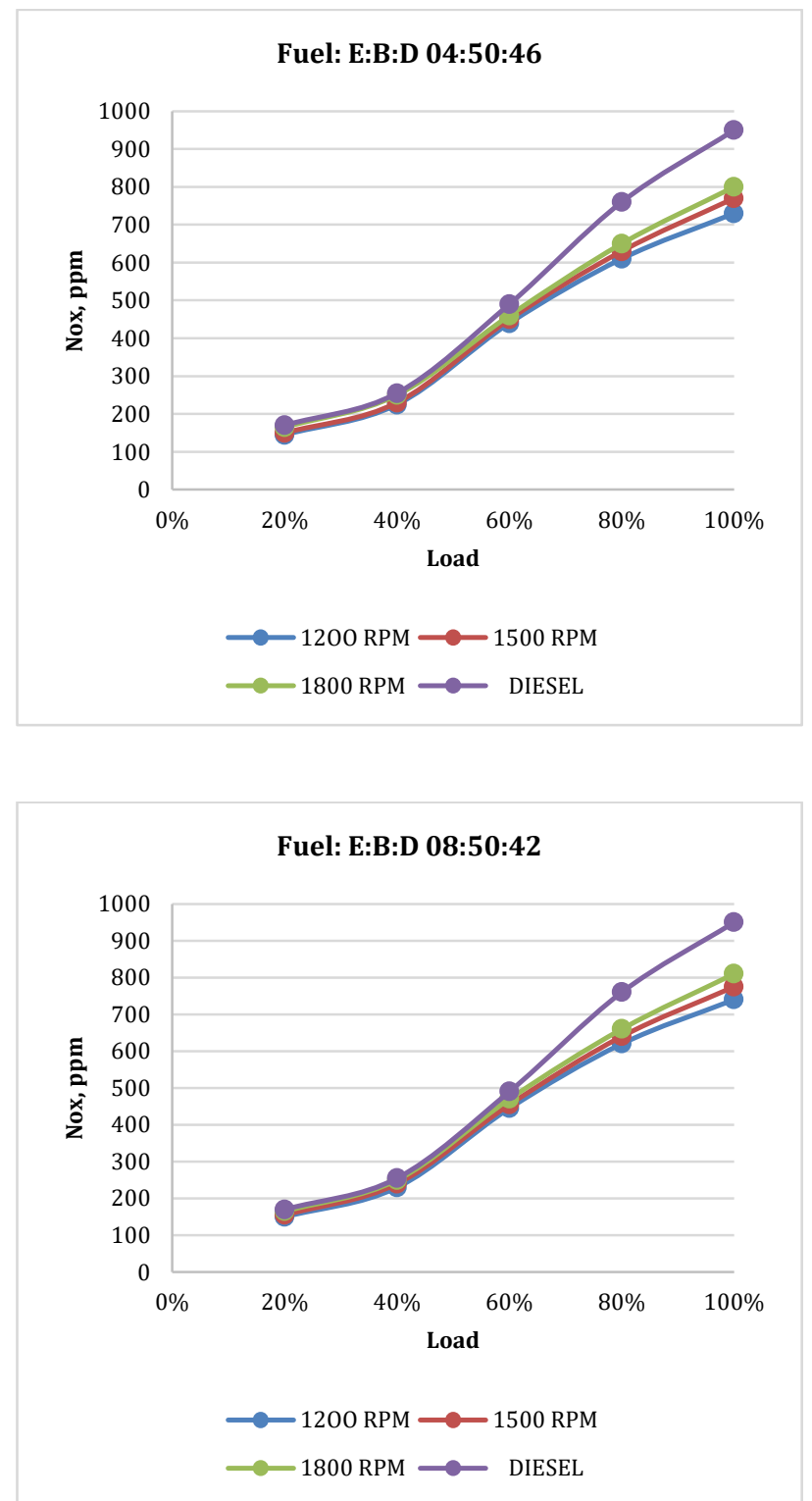
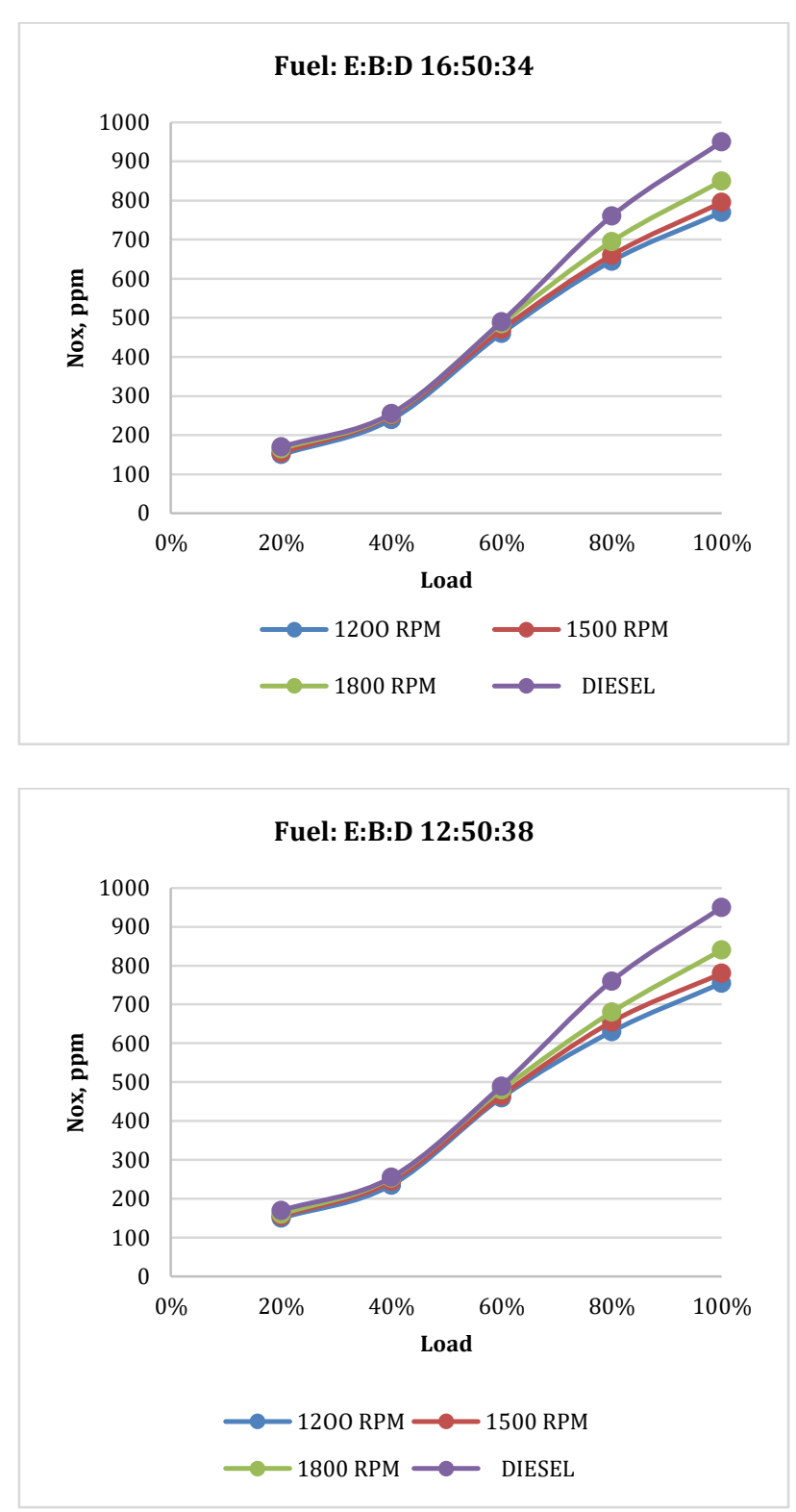

Figure 6 Effect of speed on NOx emission of fuel blends at different loads

Figure 6 shows the effect of engine speed on NOx emissions of CRDI engine for selected fuel blends operation at different loads. The rate of NOx formation is primarily a function of flame temperature, the residence time available at that temperature, and availability of oxygen in the combustion chamber. At higher engine load increased quantity of injected fuel gets combusted in the cylinder and causes higher gas temperature and results in more NOx formation in the engine cylinder. NOx emissions of AOME and their blends with ethanol and diesel are comparatively lower than diesel as they provide lower in-cylinder peak temperature. As ethanol in the blends increases combustion temperature becomes lower due to lower calorific value and higher latent heat of vaporization of ethanol. This results in reduced flame temperature and hence lower NOx emissions occur as lesser heat energy is released after combustion. NOx emission is lower for the blends with lower percentage of diesel and ethanol 
which may be due to their lower cetane number, lower peak pressure and temperature when compared to diesel operation. The NOx emissions decreased with speeds for all blends as well as compared to diesel fuel and effect of ethanol content is not significant on this trend. The decreased combustion temperature and the residence time available for the reaction resulted in decrease of NOx emission.

\section{Conclusions}

In the present experimental study of ethanol-biodiesel and diesel blends with a fixed amount of biodiesel as a emulsifier of ethanol in diesel fuel engine performance and emission characteristics were investigated at different engine speeds in a 4-cylider, 4-stroke CRDI engine. The results were compared with base diesel fuel. The main results from this study can be summarized as follows:

1) The biodiesel derived from acid oil could be used as an effective emulsifier of ethanol in diesel fuel and contributes to more stable fuel blends.

2) The brake thermal efficiency of EBD blends is increased with increase in load and speed but showed reduced performance compared to diesel. Increase in ethanol concentration in blends slightly decreases the BTE.

3) The brake specific fuel consumption decreases with increase in load and speed for all blends but is higher compared to diesel fuel. BSFC is increased with increase in ethanol proportion in the blends.

4) Regarding exhaust emissions $\mathrm{CO}$ and $\mathrm{HC}$ emissions for all blends increases with load. Higher the engine speed lower will be the $\mathrm{CO}$ and $\mathrm{HC}$ emission. Increase in ethanol content in the blends also increases $\mathrm{CO}$ and $\mathrm{HC}$ emissions. But these emissions are higher compared to diesel.

5) NOx emission slightly reduced with AOME and their blends with ethanol and diesel compared to diesel. The NOx emissions are decreased with speeds for all blends as well as compared to diesel fuel and effect of ethanol content is not so significant on this emission.

6) It can be concluded that ethanol can be used in compression ignition engines without any modifications by blending it with diesel fuel at low concentration. The phase separation can be prevented by adding biodiesel into the blends. The optimum percentage of ethanol in this study was determined as $4 \%$ with $46 \%$ diesel and $50 \%$ biodiesel. Hence the most promising alternative fuel for both developing and developed countries will be a fuel containing biodiesel and ethanol.

\section{References}

Kraipat Cheenkachorn, Monpilai H. Narasingha and Juthawan Pupakornnopparut, (2006), Biodiesel as an Additive for Diesohol Asian Journal of. Energy and Environment. 7(01), pp 267-276
A. Demirbas, (2008), Biofuels sources, biofuel policy, biofuel economy and global biofuel projections, Energy Conversion and Management, 49, pp 2106-2116.

Y. Ma, M. Zhu, and D. Zhang, (2013), The effect of a homogeneous combustion catalyst on exhaust emissions from a single cylinder diesel engine, Applied Energy, 102, pp 556-562.

S. H. Park, and C. S. Lee, (2013), Combustion performance and emission reduction characteristics of automotive DME engine system, Progress in Energy and Combustion, 39, pp 147-168.

M. E. A. Fahd, Y. Wenming, P.S. Lee, S.K. Chou, and C. R. Yap, (2013), Experimental investigation of the performance and emission characteristics of direct injection diesel engine by water emulsion diesel under varying engine load condition, Applied Energy, 102, pp 1042-1049.

A.J. Torregrosa, A. Broatch, B. Plá, and L.F. Mónico, (2013), Impact of Fischer Tropsch and biodiesel fuels on trade-offs between pollutant emissions and combustion noise in diesel engines, Biomass \& Bioenergy, 52, pp 22-33.

Vivek pathak, Prof. Amitesh Paul, (2013), Experimental Investigation of Performance \& Emission Characteristics of Diesel Engine Working On Diesel and NOME with Ethanol and Triacetin Blends International Journal of Modern Engineering Research (IJMER) Vol. 3, Issue. 5, Sep - Oct. 2013 pp-2792-2796

C.A. Sharp, (1996), Emissions and Lubricity Evaluation of Rapeseed derived biodiesel fuel, prepared by Montana Department of Environmental Quality, Southwest Research Institute, USA, pp. 1-57.

C.-Y. Lin, and K.-H. Wang, (2003), The fuel properties of three phase emulsions as an alternative fuel for diesel engines, Fuel, 82, pp 1367-1375.

G. J. Suppes, M. Goff, M. L Burkhart, K. Bockwinkel M.H. Mason, J.B Botts and J.A. Heppert, (2001), Multifunctional Diesel Fuel Additives from Triglycerides, Energy \& Fuels, 15, pp 151-157.

G. Anastopoulos, E. Lois, A. Serdari, F. Zanikos, S. Stournas and S. Kalligeros, (2001), Lubrication Properties of LowSulfur Diesel Fuels in the Presence of Specific Types of Fatty Acid Derivatives, Energy \& Fuels, 15, pp 106-112.

D. H. Qi, H. Chen, R. D. Matthews and Y. Z. H. Bian, (2010), Combustion and emission characteristics of ethanolbiodiesel-water micro-emulsions used in a direct injection compression ignition engine, Fuel, 89, pp 958-964.

H. Aydogan, (2011), Investigation of engine performance and exhaust emission effect using bioethanol-diesel fuel blends (E-Diesel), Ph.D. thesis, Selcuk University, Konya, Turkey, 1-25.

X. Shi, X .Pang, Y. Mu, H. He, S. Shuai, J. Wang, H.Chen and R. Li, (2006), Emission reduction potential of using ethanolbiodiesel-diesel fuel blend on a heavy-duty diesel engine, Atmospheric Environment, 40, pp 2567-2574.

P. V. Bhale, N. V Deshpande, S. B. Thombre, (2009), Improving the low temperature properties of biodiesel fuel, Renewable Energy, 34, pp 794-800.

X. Lu, Z. Huang, W. Zhang, and D Li, (2005), Combustion visualization and emissions of a direct injection compression ignition engine fueled with biodiesohol, Int. J. Auto. Tech-Kor, 6, pp 15-21.

D. B. Hulwan, and S. V. Joshi, (2011), Performance, emission and combustion characteristic of a multicylinder DI diesel engine running on diesel-ethanol-biodiesel blends of high ethanol content, Applied Energy, 88, pp 5042-5055.

H. Rahimi, B Ghobadian, T. Yusaf, G. Najafi and M. Khatamifar, (2009), Diesterol, an environment friendly IC engine fuel, Renewable Energy, 34, pp 335-342. 
N. Yilmaz, and T. M. Sanchez, (2012), Analysis of operating a diesel engine on biodiesel-ethanol and biodiesel-methanol blends, Energy, 46, pp 126-129.

X. Shi, Y. Yu, H. He, S. Shuai, J. Wang, and R. Li,(2005), Emission characteristics using methyl soyate-ethanoldiesel fuel blends on a diesel engine, Fuel, 84, pp 15431549.

T. Krishnaswamy, Shenbaga Vinayaga Moorthi, (2012), Performance evaluation of diesel engine with oxygenated bio-fuel blends, ARPN Journal of Engineering and Applied Sciences, Vol 7, pp 10-14.

B P Pundir. (2007), Engine emissions: pollutant formation and advances in control technology: Alpha Science International Ltd.

K Prommes, L Apanee, Samai Jai-In., (2007), Solubility of diesel-biodiesel-ethanol blend, its fuel properties and its emission characteristics from diesel engine. FUEL, 86, pp 1053-61
D. B. Hulwan, S. V. Joshi, Y. V. Aghav, (2010) Study on properties improvement and performance benefit of Diesel-Ethanol-Biodiesel blends with higher percentage of ethanol in a multi cylinder IDI Diesel engine IJAET/Vol I/Issue II/July-Sept,2010, pp248-273.

C Sayin, (2010), Engine performance and exhaust emissions of methanol and ethanol-diesel blends. FUEL, 89, pp 3410 3415.

H.G. How, H.H. Masjuki, M.A.Kalam, Y.H.Teoh, (2014), Engine Performance, emission and combustion characteristics of a common rail diesel engine fuelled with bioethanol as a fuel additive in coconut oil biodiesel blends, Energy Procedia 61, pp 1655-1659.

L Zhu, C S Cheung, Z Huang, (2011), performance and emission characteristics of a DI diesel engine fuelled with ethanol-biodiesel blends, fuel, 90, pp 1743-50.

B. M. Kulkarni, B.G.Pujar, S Shanmukhappa, (2008), Investigation of acid oil as a source of biodiesel. Indian Journal of chemical technology. Vol. 15, pp.467-471 and thesis on Biodiesel Development and Characterization as Fuel from Acid oil: a By-product of Vegetable Oil Refineries. 